\title{
Penerapan Akad ljarah Pada Produk Pembiayaan Pengurusan Porsi Haji Di KSPPS Kopena Pekalongan Ditinjau Dari Fatwa DSN-MUI
}

\section{Danis A mwalul Fikki}

D3 Perbankan Syariah, Institut Agama Islam Negeri Pekal ongan, Indonesia

\begin{abstract}
A bstract
Purpose- This study discusses the application of the ljarah Agreement on Financing Products for the Management of Hajj Portions at KSPPS Kopena Pekal ongan Judging from the DSN-MUI Fatwa.

Methods- This research is a type of field research with a type of qualitative approach. The data used in this study are primary data obtained from interviews and secondary data obtained from research at KSPPS Kopena Pekalongan. Data were analyzed descriptively, namely data collected in the form of words, images and not numbers. The method of data collection by interviews, documents, and observations.

Findings- The results of the study show that financing using the ijarah contract has followed the rules of the MUI DSN Fatwa. It can be stated that KSPPS Kopena Pekalongan has implemented the DSN-MUI Fatwa in each of its products and the Sharia Supervisory Board has always exercised strict control over the application of fatwas at the KSPPS Kopena Pekal ongan

Implications/limitations - This study is a case study and is only carried out in one agency so that future studies can expand the study area to increase generalization.
\end{abstract}

Keywords Ijarah, Financing product for Hajj Portion Management, DSN-MUI Fatwa

Paper type Research paper

$\triangle$ Email korespondensi: danisfikki2@gmail.com

\section{Pedoman Sitasi}

Danis Amwalul Fikki (2019). Penerapan Akad Ijarah pada Produk Pembiayaan Pengurusan Porsi Haji di KSPPS Kopena Pekalongan Ditinjau dari Fatwa DSN-MUI.. SERAMBI, 1(2), 45- 54

D OI: https:/ / doi.org/ 10.36407/ serambi.v1i2.70
SERAM BI

Received 10 Jun 2019

Revised 25Jun 2019

Accepted 20 Jul 2019

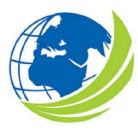

SERAMBI, Vol 1, No.2, Agustus 2019, pp. 45 - 54 eISSN 2685-9904 


\section{Pendahuluan}

Pembiayaan pengurusan porsi haji adalah salah satu produk pembiayaan yang ditawarkan oleh Koperasi Simpan Pinjam dan Pembiayaan Syariah (KSPPS) Kopena Pekalongan. Produk ini merupakan produk pembiayaan dengan akad ijarah untuk melakukan pengurusan porsi haji baik secara cash (tunai) maupun berupa talangan haji dengan jangka waktu pelunasan maksimal 5 (lima) tahun. Dalam produk ini KSPPS Kopena Pekalongan akan mengantarkan anggota untuk membuat Biaya Perjalanan Ibadah Haji (BPIH) di Bank Muamalat Indonesia dan mengantar anggota ke Kementerian Agama (Kemenag) untuk mendaftar Surat Pengantar Pergi Haji (SPPH).

Pembiayaan ijarah adalah aktivitas pembiayaan yang dilakukan berdasarkan akad ijarah yaitu akad pemindahan hak guna atas barang atau jasa, melalui pembayaran upah sewa, tanpa diikuti dengan pemindahan kepemilikan atas barang itu sendiri. Menurut wawancara penulis dengan bagian Pembiayaan Pengurusan Porsi Haji di KSPPS Kopena Pekalongan, KSPPS Kopena Pekalongan menjadikan akad ijarah sebagai akad pada produk tersebut, sedangkan dalam praktiknya KSPPS Kopena Pekalongan juga memberikan pinjaman dana kepada anggota untuk melakukan pendaftaran porsi haji. Berdasarkan Fatwa DSN MUI No. 29/ DSN-MUI/ VI/ 2002 Tentang Pembiayaan Pengurusan Haji Lembaga Keuangan Syari'ah. Dalam fatwa tersebut disebutkan ketentuan umum pembiayaan pengurusan haji lembaga keuangan syariah adalah sebagai berikut:

a. Dalam pengurusan haji bagi nasabah, LKS dapat memperoleh imbalan jasa (ujrah) dengan menggunakan prinsip al-ijarah sesuai Fatwa DSN-MUI No.9/ DSN-MUI/ IV/ 2000.

b. Apabila diperlukan, LKS dapat membantu menalangi pembiayaan pembayaran BPIH nasabah dengan menggunakan prinsip al-Qardh sesuai Fatwa DSN-MUI No.19/ DSNMUI/ IV/ 2001.

c. Jasa pengurusan haji yang dilakukan LKS tidak boleh dipersyaratkan dengan pemberian talangan haji.

d. Besar imbalan jasa al-ijarah tidak boleh didasarkan pada jumlah talangan al-qardh yang diberikan LKS kepada nasabah.

Dalam fatwa tersebut dapat dilihat bahwa lembaga keuangan syariah menggunakan akad ijarah dikarenakan lembaga keuangan tersebut memberikan jasanya berupa pengurusan porsi haji dan dapat memberikan dana pinjaman haji menggunakan akad qardh. Tetapi di KSPPS Kopena Pekalongan, Pembiayaan pengurusan porsi haji berkaitan dengan pemberian pembiayaan dana talangan haji yang diperuntukkan bagi nasabah yang ingin menunaikan ibadah haji. Produk ini memberikan bantuan kepada nasabah yang berkeinginan menunaikan ibadah haji dengan memberikan dana sehingga mendapatkan porsi haji dan kepastian kapan akan diberangkatkan untuk ibadah haji. Selain memberikan dana talangan untuk para calon jamaah haji, KSPSS Kopena Pekalongan juga membantu para calon jamaah haji dalam urusan persyaratan-persyaratan apa saja yang harus dipenuhi, serta membina dan memberikan pelayanan bagi para calon jamaah haji yang tidak tahu atau kurang paham.

Penelitian ini ditujukan untuk menjawab beberapa permasalahan sebagai berikut: (1) bagaimana Mekanisme Pembiayaan Pengurusan Porsi Haji di KSPPS Kopena Pekalongan?; dan (2) bagaimana Penerapan Akad Ijarah dalam Pembiayaan Pengurusan Porsi Haji Di KSPPS Kopena Pekalongan ditinjau dari Fatwa DSN-MUI?. Beberapa pembatasan dilakukan yaitu mengenai mekanisme pembiayaan pengurusan porsi haji dan objek akad ijarah ditinjau Fatwa DSN-MUI. Fatwafatwa yang akan digunakan, yaitu: (1) Fatwa DSN-MUI No.29/ DSN-MUI/ VI/ 2002 tentang Pembiayaan Pengurusan Haji Lembaga Keuangan Syariah; (2) Fatwa DSN-MUI No.09/ DSNMUI/ IV/ 2000 tentang Pembiayaan Ijarah; dan (3) Fatwa DSN-MUI No.112/ DSN-MUI/ IV/ 2017 tentang A kad Ijarah. 


\section{Landasan Teori}

Pengertian dan Hukum Ijarah

Al ijarah berasal dari kata al-ajru, yang arti menurut bahasanya ialah al-iwadh, yang dalam bahasa Indonesia berarti ganti dan upah. Menurut MA. Tihami, al-ljarah (sewa-menyewa) ialah akad (perjanjian) yang berkenaan dengan kemanfaatan (mengambil manfaat sesuatu) tertentu, sehingga itu menjadi legal untuk diambil manfaatnya, dengan memberikan pembayaran (sewa) tertentu.

Hukum Ijarah berasal dari AI-Q uran sebagai berikut:

Artinya: “dan jika kamu ingin anakmu disusukan oleh orang lain, $M$ aka tidak ada dosa bagimu apabila kamu memberikan pembayaran menurut yang patut. bertakwalah kamu kepada A llah dan ketahuilah bahwa Allah M aha melihat apa yang kamu kerjakan". (al-Baqarah [2]: 233)

Sementarra dari Hadist, dari sebuah dalil yang berbunyi "apabila kamu memberikan pembayaran yang patut" menunjukkan adanya jasa yang diberikan berkat kewajiban membayar upah (fee) secara patut. Dalil selanjutnya yaitu Hadits Riwayat Bukhari dan Muslim yang artinya: D iriwayatkan dari Ibnu A bbas bahwa Rasulullah SAW bersabda, "Berbekamlah kamu, kemudian berikanlah olehmu upahnya kepada tukang bekam itu" (Binti Nur Aisyah, 2015).

\section{Rukun Ijarah}

Ijarah memiliki 4 (rukun) yaitu, 'aqid (orang yang berakad), shigat akad, ujrah (upah) dan manfaat (Syafei, 2001). Dalam referensi lain disebutkan bahwa 'aqid terdiri dari 2 pihak, ang disebut mu'jir dan musta'jir, serta rukun yang keempat adalah barang yang disewakan.

Mu'jir dan musta'jir. Mu'jir merupakan orang yang menerima upah dan yang menyewakan, sedangkan musta'jir merupakan orang yang menerima upah untuk melakukan sesuatu dan yang menyewa sesuatu. Shigat, ijab kabul merupakan akad yang dilakukan antara mu'jir dan musta'jir. Ujrah (upah), merupakan upah disyaratkan diketahui jumlahnya oleh kedua belah pihak, baik dalam sewa-menyewa maupun dalam upah-mengupah. Objek Ijarah, yaitu barang yang disewakan atau sesuatu yang dikerjakan dalam upah-mengupah.

Syarat Ijarah

Syarat ijarah terdiri dari empat macam, yaitu syarat terjadinya akad (al-inqad), syarat pelaksanaan akad (an-nafad), syarah sah dan syarat lazim

Pembayaran Upah dan Sewa

Jika ijarah merupakan suatu pekerjaan, maka kewajiban pembayaran upahnya adalah pada waktu berakhirnya pekerjaan.

Fatwa DSN-MUI Nomor 29/ DSN-MUI/ VI/ 2002 tentang Pembiayaan Pengurusan Haji Lembaga Keuangan Syariah Ketentuan umum pembiayaan pengurusan haji lembaga keuangan syariah sebagai berikut:

1. Dalam pengurusan haji bagi nasabah, LKS dapat memperoleh imbalan jasa (ujrah) dengan menggunakan prinsip al-ijarah sesuai Fatwa DSN-MUI No.9/ DSN-MUI/ IV/ 2000.

2. Apabila diperlukan, LKS dapat membantu menalangi pembiayaan pembayaran BPIH nasabah dengan menggunakan prinsip al-Q ardh sesuai Fatwa DSN-MUI No.19/ DSNMUI/ IV/ 2001.

3. Jasa pengurusan haji yang dilakukan LKS tidak boleh dipersyaratkan dengan pemberian talangan haji. 
4. Besar imbalan jasa al-ijarah tidak boleh didasarkan pada jumlah talangan al-qardh yang diberikan LKS kepada nasabah.

Fatwa DSN-MUI Nomor 09/ DSN-MUI/ IV/ 2000 tentang Pembiayaan Ijarah, ditetapkan bahwa:

1. Rukun dan Syarat Ijarah

a. Sighat Ijarah, yaitu ijab dan qabul berupa pernyataan dari kedua be;ah pihak yang berakad (berkontrak), baik secara verbal maupun dalam bentuk lain.

b. Pihak-pihak yang berakad: terdiri atas pemberi sewa/ pemberi jasa dan penyewa/ pengguna jasa.

c. Objek akad ijarah adalah manfaat barang dan sewa; atau manfaat jasa dan upah.

2. Ketentuan Objek ljarah

a. Objek ijarah adalah manfaat dari penggunaan barang dan/ atau jasa.

b. Manfaat barang atau jasa harus bisa dinilai dan dapat dilaksanakan dalam kontrak.

c. Manfaat barang atau jasa harus yang bersifat dibolehkan (tidak diharamkan).

d. Kesanggupan memenuhi manfaat harus nyata dan sesuai dengan syari'ah.

e. Manfaat harus dikenali secara spesifik sedemikian rupa untuk menghilangkan jahalah (ketidaktahuan) yang akan mengakibatkan sengketa.

f. Spesifikasi manfaat harus dinyatakan dengan jelas, termasuk jangka waktunya. Bisa juga dikenali dengan spesifikasi atau identifikasi fisik.

g. Sewa atau upah adalah sesuatu yang dijanjikan dan dibayar nasabah kepada LKS sebagai pembayaran manfaat. Sesuatu yang dapat dijadikan harga dalam jual beli dapat pula dijadikan sewa atau upah dalam ijarah.

h. Pembayaran sewa atau upah boleh berbentuk jasa (manfaat lain) dari jenis yang sama dengan objek kontrak.

i. Kelenturan (flexibility) dalam menentukan sewa atau upah dapat diwujudkan dalam ukuran waktu, tempat dan jarak.

Fatwa DSN-MUI Nomor 112/ DSN-MUI/ IV/ 2017 tentang Akad Ijarah. Berikut ini merupakan fatwa terbaru mengenai akad ijarah:

1. Ketentuan terkait Shighat A kad ljarah

a. Akad ijarah harus dinyatakan secara tegas dan jelas serta dimengerti oleh mu'jir/ajir dan musta'jir.

b. Akad ijarah boleh dilakukan secara lisan, tulisan, isyarat dan perbuatan/ tindakan, serta dapat dilakukan secara elektronik sesuai syariah dan peraturan perundangundangan yang berlaku.

2. Ketentuan terkait U jrah

a. U jrah boleh berupa uang, manfaat barang, jasa atau barang yang boleh dimanfaatkan menurut syariah (mutaqawwam) dan peraturan perundang-undangan yang berlaku.

b. Kuantitas dan/ atau kualitas ujrah harus jelas, baik berupa angka nominal, prosentase tertentu, atau rumus yang disepakati dan diketahui oleh para pihak yang melakukan akad.

c. Ujrah boleh dibayar secara tunai, bertahap/ angsur dan tangguh berdasarkan kesepakatan sesuai dengan syariah dan/ atau peraturan perundang-undangan yang berlaku.

d. Ujrah yang terlah disepakati boleh ditinjau-ulang atas manfaat yang belum diterima oleh musta'jir sesuai kesepakatan. 


\section{Metode Penelitian}

Jenis dan Pendekatan Penelitian

Jenis penelitian yang penulis gunakan ialah jenis penelitian lapangan (field research) yang bersifat deskriptif kualitatif (qualitative research)

Data dan Sumber D ata

Sumber data primer adalah sumber data yang diperoleh secara langsung dari subyek penelitian (Nazir, 1988). Sumber data yang penulis peroleh langsung dari aktivitas, data penelitian ini bersumber dari aktivitas pelaksanaan akad ijarah pada pembiayaan pengurusan porsi haji di KSPPS Kopena Pekalongan. Sumber data sekunder adalah data pendukung yang diperoleh dari pihak lain yang bertujuan menganalisis data primer. Data ini antara lain berupa: dokumentasi yang berkaitan dengan akad ijarah pada pembiayaan pengurusan porsi haji di KSPPS Kopena Pekalongan.

Teknik Pengumpulan Data

Metode ini digunakan untuk mendapatkan data-data guna mengetahui secara jelas tentang akad ijarah pada pembiayaan pengurusan porsi haji dan mengadakan pengamatan secara langsung ke lapangan yaitu di KSPPS Kopena Pekalongan yang berlokasi di Jalan HOS. Cokroaminoto N0.77 Landungsari Pekalongan. Waktu penelitian dilakukan sejak tanggal 14 Mei 2019 sampai 9 Januari 2019. Wawancara atau interview adalah sebuah dialog yang dilakukan oleh pewawancara (interviewer) untuk memperoleh informasi dari terwawancara. Metode ini digunakan untuk mencari data atau informasi tentang akad ijarah pada pembiayaan pengurusan porsi haji dari responden yaitu Bapak Muhammad Budi dan Ibu Nurul Latifah selaku Staff Pembiayaan di KSPPS Kopena Pekalongan serta Bapak K.H Zuhdi Khariri selaku Dewan Pengawas Syariah (DPS) KSPPS Kopena Pekalongan.

Dokumentasi yaitu pengumpulan data verbal yang berbentuk tulisan, dokumentasi, foto, rekaman dan lainnya. Teknik ini digunakan untuk mengumpulkan data tentang personalia karyawan dan gambaran umum di KSPPS Kopena Pekalongan.

Keabsahan D ata

Triangulasi dengan Sumber Data. Penulis melakukan wawancara dengan KSPPS Kopena Pekalongan dan Dewan Pengawas Syariah untuk kemudian dibandingkan antara data hasil pengamatan dengan hasil wawancara.

M etode A nalisis D ata

Analisis data yang digunakan dalam penelitian ini adalah analisis deskriptif kualitatif, yaitu cara analisis yang cenderung menggunakan katakata untuk menjelaskan (describe) fenomena atau data yang didapatkan. Metode induktif adalah berangkat dari fakta yang khusus peristiwa-peristiwa konkrit kemudian fakta dan peristiwa yang khusus atau konkrit itu ditarik generalisasi-generalisasi yang persifat umum.

\section{Hasil dan Pembahasan}

Pembahasan

Berikut merupakan mekanisme Pembiayaan Pengurusan Porsi Haji di KSPPS Kopena Pekalongan:

1. Calon jamaah haji datang ke Kopena Pekalongan dengan membawa persyaratan yang dibutuhkan,

2. Calon jamaah haji akan mendapatkan bimbingan mengenai keterangan dan penjelasan produk pembiayaan porsi haji, 
3. Setelah memahami dan setuju, calon jamaah haji kemudian mengisi formulir pendaftaran dan mengisi akad pembiayaan, formulir pembukaan tabungan dan menandatangani surat persetujuan di atas materai oleh cal on jamaah haji,

4. Selanjutnya Kopena Pekal ongan melakukan pengecekan terhadap berkas-berkas cal on nasabah serta melakukan penilaian terhadap nasabah, serta menyiapkan dana pembiayaan yang bersumber dari anggota simpanan (Dana Pihak Ketiga/ DPK), berdasarkan wawancara penulis kepada staff pembiayaan proses ini tidak memakan waktu lama,

5. Jika pembiayaan disetujui kemudian petugas dari Kopena mengantarkan calon jamaah haji ke Bank Muamal at untuk membuat BPIH (Biaya Perjalanan Ibadah Haji),

6. Selanjutnya petugas Kopena Pekalongan mengantarkan calon jamaah haji ke Kementerian Agama untuk mendaftar SPPH (Surat Pengantar Pergi Haji),

7. Setelah selesai semua prosesnya, maka buku tabungan dari bank, SPPH, dan BPIH difotokopi kemudian berkas yang asli dijadikan jaminan atas pembiayaan oleh Kopena Pekalongan,

8. Calon jamaah haji diberikan waktu sesuai dengan kesepakatan untuk melunasi pembiayaan sejumlah angsuran yang telah disepakati pula,

9. Jika selama tiga kali angsuran berturut-turut calon jamaah haji tidak memberikan angsuran, maka akad dibatalkan, setelah sebelumnya diberikan peringatan dan mengajukan akad baru.

Ujrah yang diambil oleh KSPPS Kopena Pekalongan sebanyak Rp.5000.000,- adalah upah perhitungannya bukan melalui berapa banyak uang yang dipinjam, melainkan dari berapa waktu pinjaman, sedangkan biaya administrasi yang diperlukan kurang lebih sebesar Rp.350.000,- yang pada akhirnya akan masuk kedalam keuntungan KSPPS Kopena Pekalongan.

Setelah pembiayaan selesai, maka jaminan yang diberikan kepada KSPPS Kopena Pekalongan akan dikembalikan kepada anggota dan anggota tinggal menunggu daftar tunggu pemberangkatan haji

A kad Ijarah ditinjau dari Fatwa DSN -M UI

1. Ketentuan Umum Pembiayaan Pengurusan Porsi Haji

Dalam Fatwa DSN-MUI No. 29/ DSN-MUI/ VI/ 2002 tentang Pembiayaan Pengurusan Porsi Haji Lembaga Keuanagan Syariah, disebutkan bahwa dalam pengurusan porsi haji, LKS dapat memperoleh imbalan jasa (ujrah) dengan menggunakan prinsip ijarah. Seperti wawancara yang dilakukan oleh penulis terhadap staff pembiayaan Bapak Muhammad Budi di KSPPS Kopena Pekalongan, "Kopena tidak menggunakan akad al-qardh, Kopena hanya menggunakan akan ijarah, dan memperoleh ujrah dari pembiayaan ini". Hal ini juga serupa dengan Dewan Pengawas Syariah KSPPS Kopena Pekalongan, Bapak K.H Zuhdi Khariri, “Kopena Pekalongan mengeluarkan produk Pembiayaan Pengurusan Porsi Haji dengan akad ijarah sehingga KSPPS Kopena Pekalongan berhak atas ujrah dari pembiayaan tersebut. KSPPS Kopena Pekal ongan telah melakukannya sesuai dengan Fatwa DSN-MUI No. 29/ DSN-MUI/ VI/ 2002".

Dalam fatwa disebutkan apabila diperlukan, LKS dapat membantu menalangi pembayaran BPIH nasabah dengan menggunakan prinsip gardh. Dewan Pengawas Syariah Bapak K.H Zuhdi Khariri menyebutkan, "KSPPS Kopena Pekalongan hanya menggunakan akad ijarah dan tidak menggunakan akad qardh karena KSPPS Kopena Pekalongan merupakan lembaga bisnis yang juga berorientasi pada keuntungan untuk menjalankan perusahaan"

Jasa pengurusan haji yang dilakukan LKS tidak boleh dipersyaratkan dengan pemberian talangan haji. Sesuai dengan wawan cara penulis dengan Dewan Pengawas Syariah K.H Zuhdi Khariri, "produk ini bertujuan memberikan pembiayaan kepada calon jamaah haji yang memiliki keinginan untuk berhaji tetapi tidak memiliki dana, kemudian KSPPS Kopena Pekalongan menawarkan pembiayaan pengurusan porsi haji dengan total pembiayaan sebesar Rp25.000.000,dengan jangka waktu maksimal 5 tahun dengan akad ijarah. Namun, calon nasabah dapat memilih 
sesuai dengan kondisi ekonomi mereka, mulai dari pembiayaan penuh sebesar Rp.25.000.000,- atau dengan uang muka mulai sebesar Rp.5.000.000,- hingga Rp15.000.000,-."

Besar imbalan jasa ijarah tidak boleh didasarkan pada jumlah talangan qardh yang diberikan LKS kepada nasabah. Menurut Dewan Pengawas Syariah Bapak K.H Zuhdi Khariri, "imbalan jasa diambil dari kesepakatan antara nasabah dan KSPPS Kopena Pekalongan terkait upah dalam melakukan pengurusan porsi haji dan berdasarkan waktu pembiayaan" (wawancara dengan Bapak K.H Zuhdi Khariri, Dewan Pengawas Syariah KSPPS Kopena Pekalongan, Wawancara Pribadi, Pekalongan tanggal 09 Januari 2019). Hal serupa juga dikatakan oleh Devisi Operasional dan SDM Kopena Pekalongan Ibu Heni, "jumlah imbalan jasa ijarah diambil berdasarkan jasa pengurusan porsi haji yang diberikan oleh KSPPS Kopena Pekalongan".

\section{Rukun dan Syarat ljarah}

Dalam Fatwa DSN-MUI No. 09/ DSN-MUI/ IV/ 2000 tentang Pembiayaan Ijarah disebutkan bahwa shighat ijarah, yaitu ijab dan qabul berupa pernyataan dari kedua belah pihak yang berakad (berakad) baik secara verbal atau dalam bentuk lain. Sesuai dengan wawancara penulis kepada Dewan Pengawas Syariah, Bapak K.H Zuhdi Khariri, “KSPPS Kopena Pekalongan menggunakan akad tertulis dalam melakukan shighat ijarah, akad dilakukan diatas kertas bermaterai yang ditandatangani oleh calon jamaah haji dan KSPPS Kopena Pekalongan. Akad diatas kertas ini juga disaksikan oleh saksi sehingga dapat dipertanggungjawabkan keasliannya".

Pihak-pihak yang berakad, terdiri atas pemberi sewa/ pemberi jasa dan penyewa/ pengguna jasa, sesuai wawancara penulis terhadap Dewan Pengawas Syariah, Bapak K.H Zuhdi Khariri, "akad ijarah yang dilakukan oleh KSPPS Kopena Pekalongan merupakan akad jasa atau upah-mengupah, dimana KSPPS Kopena Pekalongan sebagai pemberi jasa dan calon jamaah haji atau nasabah sebagai pengguna jasa".

Objek akad ijarah adalah manfaat barang dan sewa atau manfaat jasa dan upah. Berdasarkan wawancara terhadap Dewan Pengawas Syariah, Bapak K.H Zuhdi Khariri, "karena akad ijarah di KSPPS Kopena Pekalongan merupakan akad upah-mengupah maka objeknya berupa manfaat jasa dan upah".

3. Ketentuan Objek Ijarah

Dalam Fatwa DSN-MUI No. 09/ DSN-MUI/ IV/ 2000 tentang Pembiayaan Ijarah disebutkan bahwa objek ijarah adalah manfaat dari penggunaan barang dan/ atau jasa. Sesuai wawancara yang dilakukan penulis kepada Dewan Pengawas Syariah, “objek ijarah merupakan jasa yang diberikan oleh KSPPS Kopena Pekalongan dalam memberikan pengurusan porsi haji kepada nasabah serta ujrah yang diambil didasarkan pada jangka waktu yang telah disepakati oleh cal on jamaah haji dan KSPPS Kopena Pekalongan".

Manfaat barang atau jasa bisa dinilai dan dapat dilaksanakan dalam kontrak. Berdasarkan wawancara penulis terhadap Dewan Pengawas Syariah "manfaat dinilai berdasarkan waktu pembiayaan". Manfaat barang atau jasa harus yang bersifat dibolehkan (tidak diharamkan), hal ini juga sesuai dengan wawancara terhadap Dewan Pengawas Syariah Bapak K.H Zuhdi Khariri, "jasa yang diberikan oleh KSPPS Kopena Pekalongan adalah membantu calon nasabah melakukan pengurusan porsi haji sehingga jasa yang dilakukan oleh KSPPS Kopena Pekalongan bersifat dibolehkan".

Kesanggupan memenuhi manfaat harus nyata dan sesuai dengan syariah, berdasarkan pengamatan yang dilakukan oleh penulis, KSPPS Kopena Pekalongan telah sanggup memenuhi manfaat jasa yang ditawarkan.

Manfaat harus dikenali secara spesifik untuk menghilangkan ketidaktahuan yang akan mengakibatkan sengketa, berdasarkan pengamatan penulis, KSPPS Kopena Pekalongan sudah 
menjalankan manfaat secara spesifik yaitu melakukan pendampingan selama pengurusan porsi haji kepada calon jamaah haji. Selanjutnya adalah spesifikasi harus dinyatakan dengan jelas, termasuk jangka waktunya. Berdasarkan wawancara yang dilakukan terhadap Dewan Pengawas Syariah, "jangka waktu yang diberikan kepada cal on jamaah haji maksimal selama 5 tahun".

Sewa atau upah adalah sesuatu yang dijanjikan dan dibayar nasabah kepada LKS sebagai pembayaran manfaat. Berdasarkan wawancara kepada Dewan Pengawas Syariah, "calon nasabah memberikan upah kepada KSPPS Kopena Pekalongan sebagai pembayaran atas jasa yang diberikan". Selanjutnya adalah pembayaran upah boleh berbentuk jasa dan kelenturan menentukan sewa atau upah dapat diwujudkan dalam ukuran waktu, tempat, dan jarak. Berdasarkan wawancara penulis Dewan Pengawas Syariah, "upah dibayarkan dalam bentuk uang dan ditentukan berdasarkan waktu".

\section{Ketentuan U jrah}

Dalam Fatwa DSN-MUI No. 112/ DSN-MUI/ IX/ 2017 tentang Akad Ijarah disebutkan bahwa ujrah boleh berupa uang, manfaat barang, jasa, atau barang yang boleh dimanfaatkan menurut syariah. Berdasarkan wawancara penulis Dewan Pengawas Syariah, Bapak Zuhdi Khariri, "ujrah yang diberikan oleh calon jamaah haji kepada KSPPS Kopena Pekalongan berupa sejumlah uang sesuai dengan kesepakatan kedua belah pihak".

Kuantitas dan / atau kualitas ujrah harus jelas, baik berupa angka nominal, prosentase tertentu, atau rumus yang disepakati dan diketahui oleh para pihak yang melakukan akad. Menurut Dewan Pengawas Syariah, besarnya ujrah berdasarkan waktu pembiayaan harus sesuai dengan kesepakatan kedua belah pihak.

U jrah boleh dibayar secara tunai, bertahap/ angsur dan tangguh berdasarkan kesepakatan sesuai dengan syariah dan/ atau peraturan perundang-undangan yang berlaku. Berdasarkan wawancara penulis kepada Dewan Pengawas Syariah, Bapak K.H Zuhdi Khariri "ujrah dibayarkan bersama dengan angsuran pokok pembiayaan setiap bulan". Ujrah yang telah disepakati boleh ditinjau-ulang atas manfaat yang belum diterima oleh penerima jasa sesuai kesepakatan, menurut penulis maka seharusnya hal ini dapat dilakukan oleh KSPPS Kopena Pekalongan.

\section{Kesimpulan}

KSPPS Kopena Pekalongan menggunakan akad ijarah pada produk Pembiayaan Pengurusan Porsi Haji, dimana KSPPS Kopena Pekalongan bertindak sebagai penyedia jasa, yaitu melakukan pengurusan porsi haji dari anggota pembiayaan. Selain itu, KSPPS Kopena Pekalongan juga memberikan pembiayaan berupa dana yang digunakan anggota untuk melakukan pendaftaran haji. Dalam mengajukan produk Pembiayaan Pengurusan Porsi Haji, calon anggota diberikan persyaratan yang mudah dan hanya dibutuhkan waktu yang singkat hingga pembiayaan tersebut disetujui. KSPPS Kopena Pekalongan kemudian membantu anggota dalam melakukan pengurusan Porsi Haji, seperti mendaftar di Bank Muamalat Indonesia untuk mendapatkan BPIH dan Kementerian Agama untuk mendapatkan SPPH. Selama proses ini, anggota tidak dimintai biaya apapun. Pada proses pengembalian juga KSPPS Kopena Pekalongan melakukan pendampingan untuk memastikan pembiayaan terselesaikan dengan tepat waktu.

Implikasi

KSPPS Kopena Pekalongan telah melakukan aktifitas pembiayaan sesuai dengan Fatwa DSN-MUI yang ada, seperti penggunaan akad pembiayaan, subjek serta objek dalam akad, serta ketentuan mengenai jaminan dari pembiayaan tersebut. Dalam pelaksanaan Fatwa DSN-MUI, KSPPS Kopena Pekalongan juga diawasi oleh Dewan Pengawas Syariah. 
Danis Amwalul Fikki / Penerapan Akad Ijarah Pada Produk Pembiayaan...

Keterbatasan dan Saran

Penelitian ini merupakan penelitian dengan pendekatan kualitatif dan naratif pada salah satu organisasi sehingga temuan penelitian lebih bersifat studi kasus dan tidak dapat digeneralisasi. Penelitian mendatang disarankan untuk memperluas objek penelitian ke organisasi lain sehingga dapat memberikan gambaran yang lebih luas dan bermanfaat untuk general isasi hasil.

\section{Referensi}

Aisyah, Binti Nur. (2015). M anajemen Pembiayaan Bank Syariah. Yogyakarta: Kalimedia.

Allahuwty, A. K. (2015). Analisis produk talangan haji di BMT An-Nawawi Purworejo (Doctoral dissertation, UIN Walisongo).

Andesta, R. (2010). Pengelolaan Pembiayaan Dana Talangan Haji Pada Bank Syariah M andiri Cabang Pekan baru (Doctoral dissertation, Universitas Islam Negeri Sultan Syarif Kasim Riau).

Angreani, P. R. (2017). M ekanisme pembiayaan talangan haji pada KSPPS Tamzis Bina U tama Cabang Pasar Induk W onosobo (Doctoral dissertation, UIN Walisongo).

Bungin, M. B. (2011). Penelitian Kualitatif. Jakarta: Kencana.

Fatwa, N. (2014). Penerapan A kad A I-Q ardh Wal Ijarah pada Produk Talangan Haji pada Pt. Bank Syariah Mandiri Kcp Sungguminasa Gowa (Doctoral dissertation, Universitas Islam Negeri Alauddin Makassar).

Fatwa DSN-MUI No.29/ DSN-MUI/ VI/ 2002 Tentang Pembiayaan Pengurusan Haji Lembaga Keuangan Syari'ah

Fatwa DSN-MUI N 0.09/ DSN-MUI/ IV/ 2000 tentang Pembiayaan Ijarah

Fatwa DSN-MUI N o.112/ DSN-MUI/ IV/ 2017 tentang A kad Ijarah

Moleong, L.J. (2002). M etodologi Penelitian Kual itatif. Bandung: Remaja Rosdakarya,

Nasrudin, M., \& Imron Rosyadi, M. A. (2017). Penerapan Fatwa D ewan Syariah N asional N 0. 29/D SN MUI/VI/2002 Tentang Pembiayaan Pengurusan Haji di BMT Surya Madani Boyolali (Doctoral dissertation, Universias Muhammadiyah Surakarta).

Nazir. (1988). M etode Penelitian. Jakarta: Galih Indonesia.

Sahrani, S dan A bdullah, R.. (2011). Fikih M uamalah. Bogor: Ghalia Indonesia.

Suhendi, H. (2005). Figh M uamalat. Jakarta: Raja Grafindo Persada.

Syafe'i, R. (2001). Fiqh M uamalah. Bandung: CV Pustaka Setia.

Yuliayu, W. S. Pembiayaan Talangan D ana U mroh M elalui Produk Ijarah Flexi Ib H asanah U mroh Pada Bank BNI Syariah Cabang Jakarta Barat (Bachelor's thesis, FAKULTAS ILMU DAKWAH DAN ILMU KOMUNIKASI UNIVERSITAS ISLAM NEGERI SYARIF HIDAYATULLAH JAKARTA 1437 H/ 2016 M). 
SERAMBI: Jurnal Ekonomi Manajemen dan Bisnis Islam

Published by LPMP Imperium 